\title{
UHRF1 wt Allele
}

National Cancer Institute

\section{Source}

National Cancer Institute. UHRF1 wt Allele. NCI Thesaurus. Code C115278.

Human UHRF1 wild-type allele is located in the vicinity of 19p13.3 and is approximately 59 $\mathrm{kb}$ in length. This allele, which encodes E3 ubiquitin-protein ligase UHRF1 protein, plays a role in both protein ubiquitination and epigenetic silencing of gene transcription. Aberrant expression of the gene is associated with many neoplastic diseases. 